\title{
Drivers of Corporate Community Involvement and Challenges in Measuring its Impact
}

\author{
Author: \\ Denni Arli* \\ Department of Marketing, Griffith Business School \\ Griffith University, Australia \\ Email: d.arli@griffith.edu.au \\ Short Bio:
}

Dr. Denni Arli is a Lecturer at the Department of Marketing, Griffith Business School, Griffith University. He has a PhD in Marketing from the University of New South Wales. His research interests include corporate social responsibility, macromarketing, social marketing, consumer ethics and religiosity. His research has been published at the Journal of Business

Ethics and International Journal of Consumer Studies.

\author{
Jack Cadeaux \\ School of Marketing, Australian School of Business, \\ University of New South Wales, Australia \\ Email: j.cadeaux@unsw.edu.au \\ Short Bio:
}

Dr Jack Cadeaux is an Associate Professor of Marketing at the University of New South Wales. He has a PhD in Marketing from the University of California, Berkeley. His research lies in distribution channels, retailing, macromarketing, strategic marketing of product and service innovations, and marketing strategy. His work has appeared in such journals as the European Journal of Marketing, Journal of Strategic Marketing, Journal of Macromarketing, the Journal of Business Research, Industrial Marketing Management and others.

*Corresponding author 


\title{
Drivers of Corporate Community Involvement and Challenges in Measuring its Impact
}

\begin{abstract}
Purpose - The aim of this study is to explore drivers of Corporate Community Involvement (CCI) initiatives and the challenges faced by companies in measuring the social impact of their initiatives.

Design/ methodological/ approach - We conducted semi-structured interviews with various Corporate Social Responsibility (CSR) or CCI managers from Australian companies and their Not-For-Profit (NFP) partners. The final sample consists of 27 managers from a mix of industries.

Findings - The study shows that stakeholder's salience may have an impact on CCI activities, especially in the area of measurements and reporting activities. Moreover, while some companies have attempted to measure the social impact of their initiatives, a large number of companies have not. This is all the more surprising given the recent focus in marketing on accountability and measurement. The results show three challenges: lack of interest, lack of resources and lack of consensus. Subsequently, we offer some research propositions to underline these challenges.
\end{abstract}

Originality/ value - This study focuses on CCI which is one of the most visible parts of Corporate Social Responsibility (CSR). It draws on interviews with various managers in charge of companies' CSR or CCI.

Keywords Corporate Social Responsibility, Corporate Community Involvement, Social Impact, Australia

Paper type Research paper 


\section{Introduction}

As the most visible part of CSR, Corporate Community Involvement (CCI) is on the rise as more companies recognise the many benefits of being socially responsible (Hess \& Warren, 2008; Scott, 2007; Smith \& Langford, 2009). Peloza (2009) suggests that firms with poor social reputations suffer stock market declines twice the size of those experienced by firms with positive social reputations. However, despite voluminous research examining CCI, a recent joint project of the Aspen Institute, Boston University and the Marketing Science Institute (2007) suggests that academics and practitioners still do not pay enough attention to measure its effects on stakeholders (Bhattacharya \& Korschun, 2007). Most of the corporate responsibility measurement guidelines, standards, and reporting frameworks that have been developed over the last decade have remained primarily at the level of capturing companies' inputs and in some cases outputs with respect to their social and community initiatives (Margolish \& Walsh, 2003). So it still largely remains the case that many CCI initiatives reported by companies merely emphasise the dollars spent or time dedicated by staff through volunteering on a particular project rather than discuss the outcomes of a particular social initiative for the intended community (Porter \& Kramer, 2007; Zappalà, 2010). Thus, the aim of this study is to increase the understanding of why companies initiate CCI and the challenges faced by companies in measuring their social impact. This study component is structured as follows: first section presents the research questions and the identified research gaps; second section discusses a review of relevant theories related to CCI literature; third section presents the proposed research methodology; fourth section discusses the findings, and finally, fifth section discusses other findings found in this study and finally, the last section presents the conclusions and limitations of this study. 


\section{Research Questions}

Much research attention has only focused on the returns for business instead of the social returns or benefits for recipients. Despite repeated calls from many researchers for more work exploring how and to what extent intended recipient benefits are measured by companies (Du et al., 2008; Kotler \& Lee, 2005), it appears that most companies are still unable to measure the impacts of their CCI (Atkinson et al., 2000; Brammer \& Millington, 2003; Zappalà, 2010). Thus, the following research questions are explored in this study:

\section{Why do companies decide to undertake and measure a CCI initiative in the community?}

There is a need to identify the reasons which lead companies to adopt and measure CCI activities. Increasingly, corporations see themselves in difficult situations, caught between critics demanding a higher level of CSR and investors applying relentless pressure to maximise short-term profit (Porter \& Kramer, 2007). One factor of a firm's success is how it manages its relationship with stakeholders. Stakeholders with differing motives will put pressure on the firm to commence CSR (Aguilera et al., 2007). However, according to stakeholder theory, it is not only the stakeholders who are able to influence the firms, but firms also have the ability to influence society and various stakeholders (Freeman, 1984). In addition, it is important to identify who is involved in the decision making process within the company. The Centre for Corporate Public Affairs' (2007) survey shows that more than $90 \%$ of the programmes were created and developed by the public affairs staff; around $60 \%$ of the time, the CEO or board are always involved in the decision process, but less than $50 \%$ are involved in developing and determining specific initiatives for community involvement. Analysis of the drivers in commencing a particular initiative would help identify why a company decided to initiate and measure a particular CCI initiative. 


\section{Why are companies unable to measure the social impact of their CCI?}

It appears that most companies are still unable to measure the impact of the CCI even though research shows that information about companies' social and ethical behaviour would influence what consumers buy (Pomering \& Johnson, 2009). According to Morimoto et al. (2005), there is little agreement between corporations regarding CCI measurement. As discussed in the literature review, there are several external CSR or CCI reporting guidelines or standards used by corporations, but these are still in their infancy with much scope for improvement. The use of reporting guidelines is voluntary and not externally assessed. According to Kotler and Lee (2005), of all the best practices related to CCI, evaluation strategies are the least developed and researched. This study will explore what are some of the challenges in measuring the impact of CCI activities.

\section{Literature Review}

The purpose of this literature review is to establish a theoretical framework relevant to CCI, and to define key terms, definition and terminologies. We will examine current practices in CCI. This review will assist us in identifying research gaps within CCI studies. The first stream of the review deals with stakeholder and public choice theory. The second stream of research deals with CCI definitions, externalities, strategies, measurements, and consequences. Consequently, initial working propositions will be developed and subsequently refined by results from the empirical research to address the research questions.

\section{Stakeholder Theory and Public Choice Theory}

A compelling argument which explores why companies are motivated to invest in social responsibility programs can be found in the domains of stakeholder theory (Argandona, 1998; Harvey \& Schaefer, 2001; Pirsch et al., 2006; Post, 2003) and public 
choice theory (Buchanan, 1973; Russel, 1979). When engaging at the micro-level, engagement with identified stakeholders, a stakeholder approach is deemed as the most appropriate theory to explain managerial behaviour (Deegan, 2002; Van der Laan, S. 2009).

We will first discuss the concept of stakeholder theory followed by a discussion of public choice theory. Clarkson (1995) developed a stakeholder theory framework incorporating employees, shareholders, customers, suppliers and public shareholders/ investors. The theory can be used to explain specific corporate characteristics and behaviours; identify the connections between stakeholders, and interpret the functions of companies (Brammer \& Millington, 2003; Donaldson \& Preston, 1995; Maignan \& Ferrell, 2004). However, Mitchell, Agle, \& Wood, 2007 contend that the framework does not separate the level of importance between the primary and the secondary stakeholders. In addition, it is still unclear what 'salience' or degree managers give priority to amongst competing stakeholder claims. Wood and Jones (1995, p. 243) suggest that empirical research in CSR and stakeholder relationships must be concerned with: “(1) which stakeholder is setting the expectations that are relevant to the CSR being used; (2) which stakeholders experience the effects of company behaviour; (3) which stakeholder is evaluating the company's performance (and on what basis does the stakeholder evaluate performance); and (4) which stakeholder is acting with respect to the firm”. Therefore, in order to identify the stakeholder' salience, Mitchell et al. (1997) proposed that managers response will be based on whether each stakeholder possesses these attributes: power (the ability of those who possess power to bring about the outcomes they desire); legitimacy (a generalized perception or assumption that the actions of an entity are desirable or appropriate within some socially constructed system of norms, values \& beliefs); and urgency (the degree to which stakeholder claims call for immediate action). The salience of a particular stakeholder to the firm's management is 'low' if only one attribute is present, 'moderate' if two attributes are present, 
and 'high' if all three attributes are present (Mitchell et al., 1997; Wood, 1991). In regards to CCI, Mitchell et al. (1997) categorised corporate philanthropy recipients as a 'discretionary stakeholder'. This stakeholder lacks both of power and urgent claims and puts no pressure on managers to engage with it in an active relationship. This condition may then influence the nature of community involvement launched by corporations (Brammer \& Millington, 2003).

Furthermore, the drivers behind a companies' decision to get involved in CCI activities can also be explained through the lens of public choice theory (Buchanan \& Tullock, 1962). The theory explains how human society makes decisions about their collective lives (Russel, 1979). Rooted in economics, public choice theory suggests that companies, individuals, and politicians are assumed to first seek their own self-interest then others. When companies are responding to the need of various stakeholders, they will eventually obtain the benefits from those activities. There is a calculation on the cost and benefits of an action taken by individuals or companies. While CCI is sometimes costly or inconvenient at present, it will bring long term benefits for the company (e.g., retention of staff, attract ethically conscious customers, lead to a reduction in cost through recycling). Public choice theory claims that politicians and voters are making decisions not in terms of public interest but in terms of their own benefits (Russell, 1979). Similarly, this concept is reflected through the importance of sustainability of a CCI program through both profit generation and social benefits. This concept is commonly known as enlightened self-interest (Keim, 1978). Through profit or benefit generation, companies are able to sustain their contributions to the community. From a public choice perspective, when there is no benefit associated with CCI, companies will be less likely to invest in CCI. They are first selfseeking rather than maximizing public interest. 
In addition to deliver the benefits for both companies and societies, there are increasing pressures from both the internal (i.e., employees) and the external stakeholders (i.e., Not-For-Profits (NFP), governments and investors) to report their non-financial performance as well as their financial results. A recent report shows that $\$ 1$ out of every $\$ 9$ under professional management in the US now involves an element of socially responsible investment (The Economist, 2008). As a response, companies now are adopting CCI to protect their reputation. However, despite increased attention toward CCI, most companies have not clearly understood the impact of their CCI to the extent that as it produces externalities to recipients. Externalities are costs or benefits which are not transmitted through price and are known as spillover benefits or external benefits (Buchanan \& Faith, 1981; Cadeaux, 2000). Daudigeos \& Valiorgue (2011) argue that how firms face different social issues depends on the type of 'negative externalities' they impose on their particular's stakeholders. As argued by Crouch (2006, p. 1536), the 'central premise of CCI resides in companies tacking ownership of the generally negative externalities they generate'. Various studies have explored externality as a concept for understanding and defining CCI (e.g., Daudigeos \& Valiorgue, 2011; Arcelus \& Schafer, 1982; Crouch, 2006). However, companies have overlooked the impact of external and internal benefit generation as a result of consumption of various products or services. By definition, a public good is a good that is non-excludable and non-rivalrous in use and supply. Non excludable means that no one can be excluded from using the good, while non-rival means the consumption of the goods by one person will not reduce the supply and availability of the goods (Cowen, 1985). Public goods produced through CCI activities may fall under one of these categories. For example: the Bill and Melinda Gates foundation currently provides free vaccination for children in the developing countries to avoid diarrhoea and pneumonia. The vaccine, as private goods, will produce external benefits through the reduction of number of people infected by the bacteria 
that cause pneumonia, thus potentially reducing the spread of bacteria to others. In another example, Pfizer provides training and education for employees on HIV/ AIDS prevention which includes information on safe sexual practices and prevention of sexually transmitted disease. Gaining knowledge on HIV infection control (which is itself a public good) will yield external benefits. Employees are being encouraged to engage in safer sex practices.

Daudigeos \& Valiorgue (2011) applied Samuelson’s (1954) concept of public good which also characterized goods in terms of two core analytical dimensions: rivalry and excludability for negative externalities. An externality is rival when a stakeholder affected by the externality effect alleviates the deterioration in the welfare of other stakeholders. While, such an externality is excludable when there are options for factoring out (i.e., neutralizing) or ring-fencing (i.e., shielding) deterioration to others’ welfare. Consequently, Daudigeos \& Valiorgue (2011) integrate the two concepts to categorize negative externalities. These externalities are then classified into four core categories: public externalities, common-pool externalities, club externalities and private externalities (see Table 1).

\section{Insert Table 1 About Here}

Moreover, McWilliams \& Siegel (2001) suggest that CCI activities can be viewed as a supply and demand model where companies are prioritizing their activities based on stakeholders' salience. Companies need to consider the effects of their activities on all constituencies (Mohr \& Webb, 2005). For example, a recent extreme case of 'British Petroleum (BP) oil spill' in the Gulf of Mexico. As a consequence, BP has to put all of its resources to address this issue. BP was required to provide intense reports on the clean-up progress and impact of its oil spill. However, when the externalities produced by a company are insignificant, a company may not be obliged to measure and report the impact of its initiatives. Therefore, addressing the first research question, companies' motives toward CCI 
activities will be influenced by stakeholders' salience. The discussions above leads to the following initial working propositions:

Proposition 1: Stakeholders' salience and negative externality will influence companies' motives toward CCI initiatives and influence their propensity to measure and report the impact of their initiatives.

\section{Corporate Community Involvement}

The concept of Corporate Social Responsibility (CSR) is usually applied to corroborate the idea that companies have obligations beyond shareholders and one of the key components of CSR which often is used to address stakeholders is Corporate Community Involvement (CCI) (Zappalà \& Cronin, 2002). Corporate Community Involvement is perhaps one of the most visible aspects of CSR and the predominant manifestation of CSR practices among Australian business (Cronin et al., 2001). A CCI initiative is about interaction between a company and its immediate environment (Bronn, 2006). The London Benchmarking Group (LBG) (2008, p. 2) identified community involvement as the 'wider contributions the company voluntarily makes to the community, usually through partnership with charities and community-based organisations'. CCI is typically interpreted as a prosocial orientation which may require service to benefit the community and which could produce positive impacts or benefits (e.g., healthier communities, improved morale) or negative impacts on communities (e.g., greenwashing or using CCI to mislead consumer's perceptions of a product) (Carroll \& Buchholtz, 2000; Garcia et al., 1999).

CCI strategies may range from donation activity at the discretion of management without an expectation of a profit return, to complex business and community partnerships that are integrated into a business strategy (Centre for Corporate Public Affairs, 2000; Zappalà, 2004). CCI enlarges the definition of good citizenship to include contributing time, products, money, services, leadership or other resources to the community in which the 
company operates (Centre for Corporate Public Affairs, 2000). More recently, CCI has moved from the periphery to being an integral component of the firm's business strategy with a pre-determined amount of resources placed in the corporate annual budget cycle (Allen, 2008). A study reveals that only $9 \%$ of companies now report that their CCI are not aligned at all with specific business or industry interests (Allen, 2008). Companies have now shifted their emphasis on CCI activities as pure philanthropy, to consider such activities as strategic ways to develop competitive advantage. When a company is able to implement a CCI programme effectively, it will improve its corporate image and reputation. This will become another source of competitive advantage, with the expectation that the programme is hard to imitate by others (Hess et al., 2002; Matten \& Crane, 2005; Waddock \& Boyle, 2002). Thus, firms are devoting a growing amount of resources to support various community projects (Kotler \& Lee, 2005).

\section{Strategies}

Businesses can adopt a variety of strategies for conducting business effectively in communities. Most CCI strategies are considered discretionary. These activities are not mandated by law; instead it is still a voluntary commitment a company makes in choosing and implementing these initiatives (Gyves \& O'Higgins, 2008; Kotler \& Lee, 2005). CCI strategies used by corporations in the domain of community involvement/ support fall into four categories: (1) donation, (2) employee volunteering, (3) non-partnership, and (4) partnership. In the financial donation strategy a corporate entity provides fixed funds or donates a percentage of revenue to a specific cause. Financial donation can include sponsorships (Maignan \& Ralston, 2002; Lyons \& Zappalà, 2008); cause related marketing (Kotler \& Lee, 2005); and ‘check book’ philanthropy (Galbreath, 2006; Zappalà, 2004). The second strategy is volunteering which encourages or allows employees to volunteer their time 
to support local communities (Austin, 2000; Kotler \& Lee, 2005; Maignan \& Ralston, 2002; McDonald \& Warburton, 2003; Zappalà, 2004). The third strategy of non-partnership involves working directly with the recipients in the community (Hess et al., 2002), and the fourth strategy is partnership, where an organisation works with one or more non-profit organisations to address a social issue (Berger et al., 2004; Lyons \& Zappalà, 2008; Porter \& Kramer, 2007; Reed \& Reed, 2009). Porter and Kramer (2007, p. 12) recommend that "the more closely tied a social issue is to the company's business, the greater the opportunity to leverage the firm's resources and capabilities, and benefit society.” Similarly, a recent survey shows that CCI character has changed from a disaggregated philanthropy activities to selective and deeper partnerships with NFP partners where companies attempt to link their core business with the needs of the community (The Allen Consulting Group, 2007). For example: Microsoft nurture information technology skills in various community colleges in the US; GlaxoSmithKline extends access to medications (Heslin \& Ochoa, 2008).

Researchers have conducted various studies to identify the success factors of CCI. The findings lead to two major recommendations. First, connecting CCI initiatives with the core business of a corporation will increase the effectiveness of an initiative (e.g., Barney, 1991; Barone et al., 2000; Hess et al., 2002; Kotler \& Lee, 2005; London \& Hart, 2004; Porter \& Kramer, 2007; Prahalad, 2005; Smith, 2003; Weaver et al., 1999). Second, partnership with non-profit organisations will also increase the effectiveness of an initiative (Austin, 2000; Berger et al., 2004; Korten, 1980; Kotler \& Lee, 2005; London \& Hart, 2004; Prahalad, 2005). Moreover, Porter \& Kramer (2007) recommend that every company sort and rank social issues in terms of potential impact. These will vary from business unit to business unit, industry to industry, and place to place (Porter \& Kramer, 2007). We summarise research on various types of CCI strategies in Table 2. Consequently, addressing 
our first research question, the above discussions lead to our second and third working proposition:

Proposition 2: $\quad$ Increased alignment between CCI initiatives with the core business will increase the effectiveness of CCI initiatives and therefore increase companies' propensity to report and measure the impact of their initiatives.

Proposition 3: Partnership with not-for-profit organizations will increase the effectiveness of CCI initiatives and therefore increase managers' propensity to measure and report the impact of their initiatives.

Insert Table 2 About Here

\section{CCI impact and reporting}

Most research on the impact of CCI mainly analysed the business benefits toward corporations (e.g., Du, Sen \& Bhattacharya, 2008). Some of the benefits found include a positive impact on the present value of a firm's cash flow (Godfrey, 2005; Hamilton et al., 1993; McWilliams \& Siegel, 2001; Orlitzky et al., 2003; Waddock \& Graves, 1997); an increase in positive attitude toward the company and/or the brand (Brown \& Dacin, 1997; Kotler \& Lee, 2005; Lichtenstein et al., 2004); as an insurance policy in a crisis situation (Dawar \& Pillutla, 2000; Ricks, 2005); a positive spill-over effect to strategic alliances (Beckmann, 2007; Cornwell \& Smith, 2001; Lafferty \& Goldsmith, 2005; Ross et al., 1992); and providing social license or approval from the local communities in areas where they operate (Gyves \& O'Higgins, 2008; Ellis, 1984; Wheelams, 2007). However, research studying the impacts or consequences of CCI on the recipients, the unexamined stakeholder group in the community, is still very limited (Du et al., 2008; McWilliams et al., 2006).

Furthermore, in order to show a company's accountability to stakeholders, measuring and reporting are important aspects of a CCI (Holland \& Gibbon, 2001). Zadek (2001) suggests that the purposes for measuring CCI are: (1) to identify what they are trying to accomplish and how best to measure performance against their aims; (2) to identify the implications of their initiatives; (3) to understand in what ways, if any, they can clarify their 
actions to increasingly sceptical and aggressive stakeholders; (4) to identify whether there are practical alternatives for improving their social performance in ways that will not harm their business performance and in many cases improve it. As the amount of resources contributed to socially responsible companies is increasing, demand for social impact measurement is also growing rapidly (Saul \& Moroni, 2008). Hence, CCI measurement efforts will eventually increase stakeholder's confidence in the authenticity of a program. For nonfinancial performance measurement, there are various standards, guidelines and auditing techniques which a company can use to measure, evaluate and report their CSR community initiatives. Some examples are: (1) Dow Jones Sustainability Index; (2) the Global Reporting Initiative; (3) London Benchmarking Group; (4) AccountAbility: AA1000Assurance Standard; (5) Business in the Community; and (6) World Business for Council for Sustainable Development. Nevertheless, all of these reporting guidelines are at an early stage of development. These organisations only provide general guidelines for standard reporting and it is still up to the corporation as to what they measure (Rosthorn, 2000). There are also still many disagreements on what terms imply and the differences between them and the criteria used in the rankings also vary widely (Chatterji \& Levine, 2006; Porter \& Kramer, 2007; Starkey \& Welford, 2001).

Similarly, Porter \& Kramer (2007) contend that many initiatives reported by companies merely emphasise the dollars spent or time dedicated for volunteering, but rarely discuss the impact an initiative has on a community. Hansen \& Schrader (1997) found that 75 percent of Germans feel inadequately informed about the social impact of business activities. Similarly, 70 percent of UK consumers agree that businesses do not pay enough attention to their social responsibilities (Dawkins, 2004). Other researchers voice a similar concern as to what extent the intended recipients benefit from CSR initiatives (Blowfield, 2007; Drucker, 1984; Gourville \& Rangan, 2003; Horin, 2007; Kotler \& Lee, 2005; Raghubir 
et al., 2008; The Centre for Corporate Public Affairs, 2007). It is clear that measuring the impact of CCI on business and society is still a challenge for many businesses. As previously discussed, there is little agreement regarding CCI measurement. Research into consequences can help companies to identify the positive and negative impact, inform decisions about when to start and when to limit such corporate involvement, and direct policies for managing the consequences in the community (Margolis \& Walsh, 2003). We summarise research on CCI consequences in Table 5. Finally, addressing our second research question, the above discussions lead to our fourth and fifth working proposition:

Proposition 4: Social impact measurements are strongly influenced by the availability of an agreed measurement tool.

Proposition 5: The inclusion of social impact measurement will increase authenticity of CCI programs perceived by the organisation.

Insert Table 3 About Here

\section{Research Method}

\section{Data Collection - In depth Interviews}

In order to describe and understand the drivers of CCI and challenges managers face in measuring the social impact of their CCI activities, we used a qualitative approach. We were especially interested in analysing the activities of companies who are actively involved in CCI activities. The unit of analysis is the company CCI initiatives. Two criteria were established for selecting the companies to study: (a) the size of the company - the sample is restricted to companies with 200 or more employees (Australian Bureau of Statistics, 2001) since large companies have greater capacity to initiate and to manage more complex CCI initiatives (Jenkins, 2006; Quaak et al., 2007) and (b) the level of CCI based on companies’ Corporate Social Responsibility (CSR) publications (such as reports, websites, and public statements) which suggest the companies recognise the trend towards higher social demands 
from the public, and that they are actively pursuing a socially responsible image (Gossling \& Vocht, 2007; Mah, 2004). In terms of data collection, a major part of our data collection effort consisted in conducting semi-structured interviews with managers involved in CCI activities. List of companies from the not-for-profit organisations in Australia focusing on CSR (e.g., St. James Ethics Center, Center for Social Impact) were used to identify firms and respondents. An introduction letter was first sent to the appropriate managers followed by a courtesy call to confirm their availability. Each interview lasted approximately 45- 60 minutes with the face-to-face interviews recorded and the audio records transcribed by professional transcribers for further analysis.

We conducted semi-structured interviews with various CSR or CCI managers from Australian companies and their Not-For-Profit (NFP) partners. Participants were asked identical questions, but the questions are designed so that responses are open-ended. The questions were-self designed based on the previous literature reviews in order to address our research questions (see Table 5 for a list of interview questions). The interviews were carried out over a period of eight months. We aimed to achieve data saturation during our data analysis process (Creswell, 1998). Thus, the final sample consists of 27 managers from a mix of industries (see Table 4). The majority of companies interviewed are listed in the Australian Security Exchange, while two companies are a subsidiary of a holding company listed in the United Kingdom Stock Exchange.

In order to address the issue of validity and reliability in qualitative work (Belk \& Wallendorf, 1989; Lincoln \& Guba, 1985), transcripts were sent to each respondent to check for accuracy and necessary changes. We also complemented our analysis of each company with external CSR or CCI reports published by the company as well as internal surveys and guidelines from the organisation. The interview data were subjected to the three-phase analysis method as suggested by Miles \& Huberman (1994), data reduction, data display and 
conclusion drawing. We debriefed our analysis by periodically meeting with colleagues to critique and question our emerging interpretation. Finally, the findings have been sent to the informants for comment as part of the 'member check' process. The purpose of this process was to present the research findings to the company's managers to check the credibility of the analysis and to examine if the findings reflected the managers own experiences and perception toward challenges in measuring CCI.

Insert Table 4 About Here

\section{Findings and Discussions}

The qualitative study revealed a number of themes related to the drivers and measurement challenges of CCI. We present the themes that cut across the interviews based on the research questions below. Company and respondent' names are not identified for confidentiality reasons.

\section{Why do companies decide to undertake and measure a CCI initiative in the}

\section{community?}

\section{Theme 1: Compliance motive as employee engagement tools}

Instead of being externally motivated, a compliance motive overwhelmingly appeared in the analysis. Most companies suggested that the main driver for launching a CCI initiative is to motivate and comply with their employees. As dormant stakeholders, employees are considered the most important stakeholders in various CCI activities. It shows that companies serve the interests of others through CCI but also ultimately serve their own selfinterest through various benefits which eventually allows them to retain and attract the best employees (Swanson 1995; Zappalà 2004). The search to give workers meaning is still one of the drivers behind CCI. Recent studies of CEOs in Australia shows that the demands of young people in the firm to be comfortable with CSR (which include CCI), with many 
seeking to express their personal altruism through the workplace. Expectations of staff, especially young people, form a major and growing driver of CCI. Therefore, by associating themselves with community issues, companies demonstrate their concern for the community, which has internal and external benefits (Cave, 2002). The findings confirm other studies by Fukukawa, Balmer, \& Gray (2007) and Hess \& Warren (2008) that CCI is being used as an employee engagement tool which allows companies to retain and attract the best employees. One trend reflecting this is the increasing prevalence of volunteering and matched giving (Center for Corporate Public Affairs, 2007).

\begin{abstract}
"We also thought I think our employees are important, particularly when we look at our community partnerships, employees are very important. We use our community partnerships as a way to engage them, get them involved, give them an opportunity to, I guess, get back to the community."(General Manager Corporate Affairs, Material Company).

"I think one of the keys from a community investment perspective is of course our people and our employees because that is the vehicle. It's a very effective vehicle to engage and to really make people feel proud and really want to work for an organisation and keep working for an organisation like [name of the company] or any organisation that has a strong focus on giving back to communities in which they are operating in." (CSR Manager, Telecommunications).
\end{abstract}

\title{
Theme 2: Competition motive in order to enhance reputation
}

Some respondents reveal that they are also concerned about their relationships with other group members and pressure from other companies. They want to be perceived as a good corporate citizen by stakeholders. Corporate reputations are strongly linked to the market value of a company, which is important to shareholders (Dowling, 2006). To appease shareholders or 'definitive stakeholders' (Mitchel et al., 1997), CCI is also being used as a tool to improve corporate reputation. The results show that perceptions of external stakeholders are considered important. Interestingly, some of the financial companies reveal that public perception of banks is not good enough. Therefore, through CCI, companies try to improve their reputation in order to build long-term sustainable businesses into the future. Many companies have long sought to be good corporate citizens through involvement with the local or wider community. CCI is perceived to be able to provide a greater benefit to 
corporate reputation assets than does traditional corporate philanthropy (Hess et al., 2002). It is recognised as improving corporate reputation and brand recognition. However, as this study is focusing on CCI, profit and self-motivated motives did not appear strongly in this study. These companies explain:

"If we are trying to identify where we should be targeting, we'll look at sites or locations where we know there are, I guess, issues or opportunities to gain benefits around getting a bit of local Public Relation." (General Manager Corporate Affairs, Materials Company).

"As an energy company, you need to be seen as a good corporate citizen. So, that's where it came about. It's been in fruition now for the past five years, so I would safely say that it's because they noticed other corporates also getting onto the bandwagon and things like that." (CSR Program Manager, Energy Company).

\section{Why are corporations unable to measure the social impact of their CCI?}

The previous findings reveal that large companies are still struggling to measure their CCI impact despite strong financial resources. This study found three challenges in regards to measuring the impact of CCI.

\section{Theme 1: Lack of interest in measuring the social impact of CCI}

Companies show disinterest in measuring the social impact of an initiative with little effort made by the organisations to measure the impact of CCI. Some of these companies tried to produce reports on their CCI activities. However they have doubts about who actually reads all these reports. CCI is seen as inconsistent with contributing positively to corporate sustainability and long-run financial return. Managers have indicated that they have little knowledge of the value of measuring a particular CCI impact or the interest of their stakeholders.

\footnotetext{
"We are not big on evaluation in terms of a scientific-based evaluation and academic-based valuation, we certainly monitor our organizations.” (Head of the Foundation, Financials company).

"We wouldn't actually bother with measuring any outputs, it's not worth it, it costs more on sponsorship, and how do you ascertain whether it's been effective or not, I don't know." (Manager, Regulatory Affairs and Policy Personal Lines Insurances, Financials company).
} 
In addition, some managers commented that the business value and worth of CCI was hardest to achieve at a senior management level. A lack of knowledge in the area contributed to resistance from senior management. Since CCI impact is concerned with transparency, accountability and performance, it is important for the CCI decision-making structure to be supported by senior management because it requires intensive corporate commitment (Lewis, 2003). Lack of interest at the senior management level will eventually affect the rest of the management team. These companies explain:

\begin{abstract}
"Lack of buy-in and support from the senior management team. If it's not driven from the top, top down approach, it's extremely hard, that's one obstacle.”( CSR Manager, energy company).

"I think one of the challenges is helping senior management understand it's not just about philanthropy and it's not just about doing good or it's not just about giving money away, it's about engaged and imbedded philanthropy or engaged an imbedded partnerships that both deliver a community good, a not for profit or community organisational benefit and a business benefit. It should be a threefold outcome for everyone." (National Manager, Telecommunications Company ).
\end{abstract}

Furthermore, when there is no interest in social impact measurement, adding extra hours and effort to measure the impact of CCI can be considered a distraction from their daily business activities. As a consequence, companies are only interested in monitoring and measuring their 'flagship' program or a program where they spend the most dollars of their community investments and ignoring the rest. This flagship program allows companies to focus on initiatives which are linked to the firm core competencies. In a flagship program, companies spend considerable time planning up front. They emphasize the strategic design of their programs, set a clear mission for the function, and specify goals. This financial company explains:

"And we know from the local organisations that those small amounts of money and those contributions are very valued by the community but we don't have such a robust evaluation framework around those things. But, certainly when it comes to our flagship programs with our link to our business, we take those social issues around financial literacy in the community very seriously and we do a lot of work to try and understand those issues." (Head of Community Involvement, Financials company). 
Furthermore, with the smaller donation, companies are requesting their NFP's partners to provide reports back to the company. This evidence shows that the greater the amount of giving, the more rigorous the requirements needed. This company explains:

\footnotetext{
"As I was saying earlier about evaluation, the monitoring is out of that so I mean it depends on how much money it is, I mean you know we are realistic, if we are given $\$ 10,000$ I'm not worried about that, if I am giving them a million dollars I'd probably meet with them every month. So it depends on the amount." (Head of Group Foundation, Financials company).

"Well certainly the ones that are more expensive we certainly would be doing so. We've got small ones like the [Name of NFP partner], we help pay for them, we wouldn't measure that, it just helps fund an organisation that's supposed to, you know that's a good citizen.” (Manager, Regulatory Affairs and Policy Personal Lines Insurances, Financials company).
}

Measuring an impact is still perceived as 'well worth' having if possible but was not seen as essential. Companies have not seen the benefit of measuring the social impact of a project. They are more interested in measuring the business benefits toward their corporations such as feedback from projects, employee attitude, community stakeholders' attitude and internal customer satisfaction. This could be attributed to the fact that the drivers of many CCI initiatives are strongly associated with improving ‘corporate ethical identity’ or the set of behaviours, communications and stances that are representative of an organization's ethical attitudes and beliefs' (Fukukawa et al., 2007, p. 37). Subsequently, we found that lack of interest in measuring the social impact of CCI might lead to the next challenge where companies are not dedicating adequate resources to address this issue. Whether companies measure the effectiveness or impact of their CCI is another indicator that they see such activity as a key part of their overall business.

\section{Theme 2: Lack of time and resources in measuring the social impact of CCI}

The interview findings show that most companies do not have the luxury of a dedicated CCI department within the organisation. In many cases, the manager in charge of CCI has dual roles, such as Human Resources, Public Relations, Corporate Affairs etc., in other instances the manager in charge of CCI issues is the only person working in the 
company or part of a small team. When there is no specific CCI department within the company, often employees have to organise themselves with a particular NFP organisation if they desire to get involved in the community. Companies were reluctant to ask more of employees who already had a lot to do. These managers explain:

"Well, I actually am based in the Human Resources department. Normally, from other previous roles, I've always - with CSR or community relations, it's always been part of sort of the corporate affairs or marketing area." (CSR Manager, Energy company).

"I think it's really just time and air space, that people are very busy and so, as I said, there's a lot of goodwill but actually to try to get people to be able to stop what they're doing and focus on something else for a time is difficult and that's from the top of this organisation down to the bottom. There is a lot of interest in this [measurement] but actually we are competing with a lot of very important other pressures within the business.” (Manager, Corporate Responsibility, Telecommunications services).

Therefore, when they are faced with the challenges of measuring the impact of CCI, they simply had no time or resources available to accommodate this additional task. Measuring impact is difficult at best. It can be costly, time-consuming and technically demanding. Companies may support from as little as five to many hundreds of initiatives. Similarly, most of the NFPs are already resource constrained. Some managers reveal that to give the NFP significant reporting responsibilities is just going to redirect resources towards measurement rather than towards what a company believes is the more important work in the community. Increased Partnerships with NFPs tend to encourage companies to relegate the duties of impact measurement to NFP. With time and resource constraints, it is almost impossible to measure each initiative that they support, as explained by this Not-for-Profit's partner:

“That's quite easy to do when you're focussed on one program where you know what the parameters are, but when you've got hundreds and hundreds of different initiatives going on, it's a little bit hard to make any overarching statements about what the overall impact is." (General Manager Social Initiatives, NFP).

"We've got quite excellent impact assessment programs in place for our flagship programs. So we know, for instance, with [name of an initiative], that savings program, we've got longitudinal research that demonstrates what the ongoing impact on participants that that program has and we're up to three, or four, or five years later in longitudinal terms for participants who have participated in the program. That's quite easy to do when you're focussed on one program where you know what the parameters are but when you've got hundreds and hundreds of different initiatives going on, it's a little bit hard to make any overarching statements about what the overall impact is." (Head of Community Involvement, Financials company). 


\section{Theme 3: Lack of consensus on what and how to measure the social impact of CCI}

Most organisations admitted that they just don’t know how and what exactly should be measured. CCI does not lend itself easily to dollar quantification. Some types of initiatives are easier to measure than others. The value to a firm of sponsorships, for example, can be assessed more easily than partnerships and initiatives associated with poverty reduction or drug rehabilitation. Many elements of social impact are considered intangible, complex, and difficult to measure. The complexity of measurement often prevents many companies from participating in CCI activities, since they are not sure how they can evaluate their impact (Peters, 2001). For example, a significant challenge to measuring the impact of CCI is causality. It is very difficult to state definitively that a positive social impact was caused solely by a specific set of CCI or because of other factors. There are perceptions that social impact cannot be measured, not clearly defined, and is considered work in progress. These companies explain:

\footnotetext{
"So I guess that would be the main challenge is to separate exactly how much of that particular person's situation is directly benefited by our involvement or whether other factors are causing it as well.” (Financial, Sustainability Manager, Financials company).

"That is probably the single hardest thing to do. Because how do you measure whether you've improved social cohesion for example?."(Project Director, Material company).
}

The task is made even more difficult when it is realised that many social impacts are seen over a long time. Many of the recipients are no longer connected to the organisations. The nature of most CCI initiatives is as a one-off activity. Once the recipients joined the program, they are expected to graduate and not return to the program anymore. For example: in a drug rehabilitation program for youth; the youth are trained and expected to be independently free from drugs. Once they are free from drugs, they no longer need assistance from the organisation which makes it challenging to relate them to community investment, as argued by this manager: 
"That's a tough one, simply because to measure impact you really need a longitudinal study and a lot of our clients are transient. We are not always able to keep track of them long term. Also with [Name of the company], it's been around for five years and we have data from over those five years but we don't always have a young person stay with the program for five years." (Manager, Corporate Partnership, NFP).

Consequently, the majority of social reporting is qualitative. The social impacts of CCI tend to be easily measured qualitatively as opposed to quantitatively. Qualitative information refers to the description of activities that the company has actually conducted and reflects how the company has implemented certain initiatives (Global Reporting Initiative, 2008). Therefore, most CCI impact was measured by anecdotal evidence such as a short case story gathered by NFP partners who have been benefiting from CCI initiatives. This company explains:

"It's pretty visible, and you do get anecdotal feedback back and you get loads of thanks and things like that." (General Manager Corporate Affairs, Materials company).

"I don't think that we have one really robust impact assessment tool that we can use that makes all of that hang together yet. I think we're still telling individual stories from within the programs and then surmising a lot about the total picture, but we don't really have a concrete impact assessment methodology for the whole program." (Project Director, Materials company).

However, a critique might be that some companies use this story to divert attention away from the issues of social impact or 'greenwash' their current operations (Adams \& Evans, 2004). In addition to reporting their CCI impact through stories, companies also attempt to measure outputs of their CCI with what is visible and convenient to them, such as how much money is invested, how many employees are involved and how many organisations received their assistance. Unfortunately, the measurements that are easiest to report are not always the most informative (Chatterji \& Levine, 2006). Most companies still undervalue and under record the total amount of contributions they make to the community. In many cases, companies don't track the full amount of philanthropic grants they make because grants are embedded in budgets across various departments, business lines, and sites. The problem gets worse when companies try to track non-cash contributions such as in-kind 
donations, employee volunteer time, and loaned expertise. Eventually, some companies have to develop their own survey, as explained by this company:

"If we put a campaign out to get more donors through payroll giving, and the measurement will be from that campaign, how many people actually signed up from that promotion campaign. That's how we measured, not as an overall thing at the moment." (Energy, CSR Manager, Energy company).

"I think, well, because of that criteria of looking at people, I suppose, it's like how much employee engagement has it been around particular partnership in a year. So, we would measure participation rates, how many hours? how many employees affected, how many benefited from it? I guess then, what we do is each year is have a look and compared with last year, is it growing?, is it reducing? with the partnership like [Name of NFP] and successes is around how much money was raised where that money is gone. So, we have monitored the research that goes on where the money is invested, and similarly, How many people have gone to the walks, how many participated in the ride?" (General Manager Corporate Affairs, Materials company).

There are various other approaches used by companies. Some make use of a ratio to put some metrics together and get a sense of what is being accomplished. This is assessed against internally established targets. However, it shows that some of the targets and goals are usually very vague and cannot be measured easily (e.g., being a good neighbour in the community, maintaining a good relationship with the community). Others chose to enlist the services of a third party to assess impact based on a set of agreed criteria. Some companies are becoming a member of external organisations which focus on community involvement. However, some companies who have attempted to link their core competencies with their CCI activities tend to measure the impact of their CCI initiatives. In this study, the most prominent third party CCI organisation which appeared the most during the interview is the London Benchmarking Group (LBG). The aim of this group is to guide large companies on how to give something back to the community. Companies are able to track their investment involving everything from money and in-kind donations to employee participation (London Benchmarking Group, 2008). These companies explain: 
"So the LBG model gives us an opportunity to capture that information and put it all, using some very simple parameters, in one place. And then you start to see impact in terms of, first of all, how big is the contribution. Sometimes I think it's hard, unless you actually have a tool like LBG to really know what you're spending and what the total of that is. So it gives us an opportunity to see the cost impact, I guess, for the community through LBG. But then, the bigger question of what the impact in the community and for the business are over, perhaps a longer term. That's a difficult one to measure as on exercise across the whole community investment program" (Head of Community Relations, Financials company ).

"We're part of a membership called London Benchmarking Group, and that is sort of measuring how much you're putting inputs and then what the outputs are, and then also comparing within that sector" (CSR Manager, Energy company).

While the literature suggests that companies need to measure the impact of their CCI, various metrics suitable for social impact measurement are not widely known to companies and when managers are faced with the numerous metrics of non-financial performance measurement systems, the natural response is to ignore them (Chatterji \& Levine, 2006). Many social indicator metrics are still at the early developmental stage with only limited numbers of firms measuring such issues in a consistent and frequent manner (Suggett \& Goodsir, 2002). Chatterji \& Levine (2006) contend that there are still no generally accepted models and tools for auditing the social impact of CCI initiatives. Although the Global Reporting Initiatives (GRI) and LBG have made a significant contribution to provide guidelines for measuring social impact, these organisations do not provide an overarching approach to measure the social impact of CCI. As a result of this non-agreement on the best set of metrics, combined with inherent difficulties in understanding and defining what social impact is, the organisations only emphasise the elements and aspects of 'social' which best suit them (Sriramesh, et al., 2009; Henderson, 2001).

\section{Other Findings}

The purpose of this section is to address the research questions and discuss other findings found in this study. The section begins by first reiterating the propositions and then presenting the other findings. This section ends with a discussion of the implications of the 
propositions and other findings on the existing CCI practices and research. Below are the propositions:

1. Why do companies decided to undertake and measure a CCI initiative in the community?

Proposition 1 : Stakeholders' salience and negative externality will influence companies' motives toward CCI initiatives and influence their propensity to measure and report the impact of their initiatives.

Proposition 2 : Increased alignment between CCI initiatives with the core business will increase the effectiveness of CCI initiatives and therefore increase companies' propensity to report and measure the impact of their initiatives.

Proposition 3 : Partnership with not-for-profit organizations will increase the effectiveness of CCI initiatives and therefore increase managers' propensity to measure and report the impact of their initiatives.

2. Why are corporations unable to measure the social impact of their CCI?

Proposition 4 : Social impact measurements are strongly influenced by the availability of an agreed measurement tool.

Proposition 5 : The inclusion of social impact measurement will increase the authenticity of a firm's CCI program perceived by the organisations.

The findings mostly support our propositions, it shows that reporting activities are higher when they are aimed at higher salience stakeholders with power, urgency and legitimacy (i.e., shareholders) versus lower salience stakeholders with power and legitimacy (i.e., employee) or stakeholders who possess legitimacy only (i.e., recipients). Companies heavily publicize their financial investment in CCI, to show commitments to higher salience stakeholders, while the impact on the CCI recipients as lower salience stakeholders are less understood. Studies show that stakeholders seek information not only of firms CSR or CCI activities but also about the social impact of those practices (Wood, 1991). This will eventually affect companies' decisions coupled with the support from senior level management toward social impact measurements. Moreover, based on the previous analysis, we offer new findings: 
Proposition 1a : High stakeholder salience, shown by the strong presence of power, legitimacy and urgency, will influence managers' motives toward CCI initiatives and increase managers' propensity to measure and validate the impact of their initiatives.

Proposition 1b : Low stakeholder salience, shown by the weak presence of power, legitimacy and urgency, will influence managers' motives toward CCI initiatives and reduce their propensity to measure and validate the impact of their initiatives.

The study suggests that CCI has slowly moved away from traditional corporate philanthropy in the form of cash donations to developing longer-term, multifaceted partnerships with Not-for-profit organisations (community-business partnerships). The findings with respect to this area suggest that community-business partnerships are becoming a central element of the CCI practices of large companies. However, cash donation, goods and services in kind, and employee times remain important elements of companies' CCI policies and programs and they are increasingly undertaken within the framework of strategic partnerships with not-for-profit organisations (Zappalà \& Lyons, 2008). Nevertheless, increased partnerships do not always lead to increased measurement. Consequently, we offer new findings:

Proposition 2 : Increased alignment between CCI initiatives with the core business will increase manager's propensity to measure the impact of their initiatives due to their familiarity and expertise with the activities.

Proposition 3a : Partnerships with not-for-profit organizations will increase the effectiveness of CCI initiatives however the partnerships will not always increase managers' propensities to measure the impact of their initiatives.

Proposition 3b : Companies who are unable to measure outputs with respect to business and community benefit will rely primarily on anecdotal information to demonstrate these benefits.

These findings are consistent with those of previous studies. A recent report that assessed how Australia's 50 largest publicly listed companies report on their CCI found that almost 90 per cent failed to comprehensively measure the value of their CCI programs (ACCA, 2010). While most companies recognised the strategic importance of their CCI and 
provided some public reporting of it, most of the disclosure related to inputs rather than outcomes. While most companies understood the strategic importance of their CCI and attempted to provide some public reporting, most of the disclosure relates to inputs rather than outcomes.

Studies showed that consumers have a lack of confidence toward companies' CCI claims due to attributions of self-interest to companies' actions (Barone et al., 2000; Forehand \& Grier, 2003; Lichtenstein et al., 2004; Webb \& Mohr, 1998; Pomering \& Lester, 2009). Providing specific impact measurement will distinguish between companies that are committed to CCI and those that opportunistically exploit the concept (Wood, 1991). Therefore, we offer new findings:

Proposition 4a : Social impact measurements are strongly related to the support and interest of the senior management. Lack of measurement indicates lack of support, time and interest from the senior level management.

Proposition 4b : Social impact measurements are strongly influenced by the complexity of the activities and the availability of an agreed measurement tool.

Proposition 5 : The inclusion of social impact measurements which show benefits to both company and community suggesting long term commitments toward CCI will increase the authenticity of firm's CCI program perceived by the organisations.

\section{Conclusions and Limitations}

The stakeholder approach is essential because organisations that address stakeholders' concerns perform better than firms that do not address these interests (Polonsky \& Scott, 2005). This stakeholder perspective puts the organisation at the centre of a network of stakeholders. As Mitchell et al. (1997) proposed, the key to considering appropriately identified and salience stakeholders were related to the stakeholders’ power, legitimacy and urgency. The study makes several empirical and theoretical contributions by: (1) providing evidence on the impact of stakeholder's salience toward CCI activities; (2) this study also reveals that many CCI initiatives in Australia are still based on "responsive CSR" or that the 
company is trying to become a good corporate citizen with strong trends toward strategic CSR (Porter \& Kramer 2007). It shows that the drivers of CCI are associated with providing tools to appease various stakeholders through employee engagement and reputation enhancing activities; (3) our findings also support public choice theory where companies are first motivated chiefly by self-interest instead of maximizing public interests. As a result, it still largely remains the case that many CCI initiatives reported by companies merely emphasise the dollars spent or time dedicated by staff on a particular project rather than discussing the social impact an initiative has had on the target community. When combined with a lack of support and interest from senior management, these factors will contribute to the mounting challenges faced by companies in measuring the social impact of their CCI; (4) the findings show that companies are ill-equipped to measure their impact on community welfare, social cohesion or other benefits of community involvement. This is so because the current indicators of social impact measurement (e.g., LBG, GRI) have not been shown to be valid measures of social impact (Waddock \& Graves, 1997; Porter \& Kramer, 2007).

We offer suggestions in response to our research questions. Academics, managers of corporations and NFP managers need to create greater consensus on what should be measured and which metrics to use in measuring the social impact of CCI. It is difficult to compare the results between companies when the majority of them do not apply the same standard of measurement with regard to their CCI. With simple, yet comparable measurement tools across businesses, companies and NFPs with limited resources can measure the social impact of their initiatives (Chatterji \& Levine, 2006, Maio, 2003).

Finally, as in most research, this research has limitations that affect our interpretation of the findings, while at the same time suggesting directions for future research. First, the qualitative data are collected from a few Australian companies, which means that findings cannot be generalized to ccompanies outside this continent as their legal, social, and cultural 
environments are likely to influence their CCI investments. Second, the complementary quantitative data are only from a small size sample. Moreover, we are consciously focusing on a group that has taken a keen interest in CCI and their participation in the CRI is a sign of this - in this respect the sample is weighted towards companies that have accepted the merits and necessity of CCI. Therefore, it might not be a representative sample. Further research might look at the long-term benefits of social impact measurement from the perspective of organisations and recipients. Doing so is an essential process in determining whether a CCI initiative is actually making a difference. There is a need to develop measures that are able to track social impacts over time. An impact measure that would seek to demonstrate that a strategy has impact and is generalizable to other contexts has great value to the field and is worthy of companies’ support. 


\section{References}

ACCA (2010), “Corporate Social Responsibility report 2009/2010”, Retrieved from http://www.accaglobal.com/pubs/about/reports/csr/csr0910.pdf. (accessed: 5 March 2011).

Adams, C A., and R. Evans, (2004), “Accountability, Completeness, Credibility and the Audit Expectations Gap”, Journal of Corporate Citizenship, Vol. 14, p. 97-115.

Aguilera, R. V., Rupp, D. E., Williams, C. A., and Ganapathi, J. (2007), "Putting the S Back in Corporate Social Responsibility: A Multilevel Theory of Social Change in Organizations", Academy of Management Review, Vol. 32 No. 3, pp. 836-863.

Allen, G. (2008), “Corporate Community Investment in Australia. Journal of Public Affairs”, Vol. 8, pp. 219-227.

Aman, A., Jr. (2001), "Privatization and the democracy problem in globalization: Making markets more accountable through administrative law”, Fordham Urban Law Journal, Vol. 28, pp. 1477-1506.

Arcelus, F. J. and Schaefer, N. V. (1982), "Social demands as strategic issues: Some conceptual problems. Strategic Management Journal”, Vol. 3, pp. 347-357.

Argandona, A.(1998), “The Stakeholder Theory and the Common Good, Journal of Business Ethics 17(9/10)”, pp. 1093-1102.

Austin, J. (2000). The Collaboration Challenge: How Nonprofits and Businesses Succeed Through Strategic Alliances San Fransisco: Jossey-Bass.

Australian Bureau Statistic (2001), "Small business in Australia”, Retrieved from: http://www.abs.gov.au/ausstats/abs@.nsf/0/97452F3932F44031CA256C5B00027F19?Open Document (accessed 14 July 2011).

Barney, J. (1991), "Firm Resources and Sustained Competitive Advantage. Journal of Management”, Vol 17 No 1, pp. 99-121.

Barone, M.J., Miyazaki, A.D. and Taylor, K. (2000), “The influence of cause related marketing on consumer choice: does one good turn deserve another?. Journal of the Academy of Marketing Science”, Vol. 28 No. 2, pp. 248-62.

Beckmann, S. (2007), "Consumers and Corporate Social Responsibility. Australasian Marketing Journal”, Vol. 15 No. 1, pp. 27-36.

Belk, R. W., and Wallendorf, M. (1989), “Assessing Trustworthiness in Naturalistic Consumer Research, in Special Volumes - ICR”, Association for Consumer Research, 69-84.

Berger, I. E., Cunningham, P. H., and Drumwright, M. E. (2004), "Social Alliances: Company/ Nonprofit Collaboration. California Management Review”, Vol. 47 No. 1, pp. 5890. 
Bhattacharya, C. B., and Korschun, D. (2007). Stakeholder Marketing: Beyond the 4P's and the Customer, The Stakeholder Marketing Consortium. Aspen Institute.

Brammer, S., and Millington, A. (2003), “The Effect of Stakeholder Preferences, Organizational Structure and Industry Type on Corporate Community Involvement”, Journal of Business Ethics, Vol. 45 No. 3, pp. 213-226.

Bronn, P. (2006), “Case Study, Building Corporate Brand through Community Involvement: Is it Exportable? The Case of the Ronald McDonald House in Norway. Journal of Marketing Communications”, Vol. 12 No. 4, pp. 309-320.

Brown, L. D., and Covey, J. G. (1987), Development organizations and organization development: Implications for a new paradigm. InW. Pasmore \& R.Woodman (Eds.), Research in organization change and development (Vol. 1, pp. 59-88), Greenwich, CT: JAI.

Brown, T., and Dacin, P.A. (1997), “The company and the product: Corporate associations and consumer product responses”, Journal of Marketing, Vol. 61 No.1, pp.68 $-84$.

Buchanan, J. M. (1973), “The institutional structure of externality”, Public Choice 14 (Spring), pp. 69-82.

Buchanan, J.M. and Tullock, G. (1962), “The calculus of consent: logical foundations of constitutional democracy”, Ann Arbor: The University of Michigan Press.

Buchanan, J.M. and Faith, R.L. (1981), "Entrepreneurship and the internalization of Externalities”, Journal of Law and Economics, Vol. 24, 95-112.

Cadeaux, J. (2000), "Market Mechanisms and the External Benefits of Consumption. Journal of Macromarketing”, Vol. 20, pp. 11-22.

Carroll, A. B., and Buchholtz, A. K. (2000). Business and Society, Ethics and Stakeholder Management Cincinnati, Ohio: South-Western College Publishing.

Cave, Michael (2002) 'Go ahead, motivate me!' BOSS Magazine, Australian Financial Review, June, pp. 30-36.

Centre for Corporate Public Affairs. (2000). Corporate Community Involvement: Establishing a Business Case: Centre for Corporate Public Affairs and the Business Council Australia.

Chatterji, A., and Levine, D. (2006), "Breaking Down the Wall of Codes: Evaluating Non-Financial Performance Measurement”, California Management Review, Vol. 48 No. 2, pp. 29-51.

Clarkson, M. E. (1995), “A Stakeholder Framework for Analyzing and Evaluating Corporate Social Performance”, Academy of Management Review, Vol. 20 No.1, pp. 92-117. 
Cornwell, T. B., and Smith, R. K. (2001), “The communications importance of consumer meaning in cause-linked events: findings from a US event for benefiting breast cancer research”, Journal of Marketing Communications, Vol. 7 No. 4, pp. 213-229.

Cowen, T. (1985), "Public Goods Definitions and Their Institutional Context: A Critique of Public Goods Theory”, Review of Social Economy, Vol. 43 (April).

Creswell, J. W. (1998). Qualitative inquiry and research design: Choosing among five traditions. Thousand Oaks, CA: Sage.

Cronin, C., Zappalà, G., and Clarkson, M. (2001), "Measuring the Social Impact of companies in Australia: The Smith Family's participation in the Good Reputation Index", Research and Social Policy Briefing Paper (Vol. 9).

Cropanzano, R., Rupp, D. E., \& Byrne, Z. S. (2003), "The relationship of emotional exhaustion to work attitudes, job performance, and organizational citizenship behaviors". Journal of Applied Psychology, Vol. 88 No. 1,pp. 160-169.

Crouch, C. (2006), "Modelling the firm in its market and organizational environment: Methodologies for studying corporate social responsibility”, Organization Studies, Vol. 27, pp.1533-1551.

Dacin, P. A., and Brown, T. J. (1997), “The company and the product: Corporate associations and consumer product responses”, Journal of Marketing, Vol. 61 No. 1, pp. 68-85

Daudigeos, T. and Valiorgue, B. (2011), “Conditions for Value Creation in the Marketplace Through the Management of CSR issues: A Negative External Effects Framework”, Business and Society, Vol. 50 No. 1, pp. 28-49.

Dawar, N., and Pillutla, M. (2000), "Impact of product-harm crisis on brand equity: The moderating role of consumer expectations”, Journal of Marketing Research, Vol. 37 (May), pp. 215-226.

Dawkins, J. (2004), “Corporate responsibility: the communication challenge. Journal of Communication Management”, Vol. 9 No. 2, pp. 108-19.

Deegan, C. (2002), "Introduction- the legitimising effect of social and environmental disclosures-a theoretical foundation”, Accounting, Auditing and Accountability Journal, Vol. 15 No. 3, pp. 282-311.

Donaldson, T., and Preston, L. E. (1995), “The Stakeholder Theory of the Corporation: Concepts, Evidence, and Implications”, Academy of Management Review, Vol. 20 No. 1, pp. 65-91.

Du, S., Sen, S., and Bhattacharya, C. B. (2008), “Exploring the Social and Business Returns of a Corporate Oral Health Initiative Aimed at Disadvantaged Hispanic Families”, Journal of Consumer Research, Vol. 35, 483-494.

Ellis, G. F. R. (1984), “The Dimensions of Poverty”,. Social Indicators Research, 15(3), 229253. 
Forehand, Mark R. and Sonya Grier (2003).”When Is Honesty the Best Policy? The Effect of Stated Intent on Consumer Skepticism”, Journal of Consumer Psychology, Vol. 13 No. 3, pp. 349-56.

Freeman, R. (1984). Strategic Management: A stakeholder approach. Boston: Pitman.

Fukukawa, K., Balmer, J., and Gray, E. (2007), “Mapping the Interface Between Corporate Identity, Ethics and Corporate Social Responsibility”, Journal of Business Ethics, Vol. 76, pp. 1-5.

Galbreath, J. (2006), “Corporate social responsibility strategy: strategic options, global considerations”, Corporate Governance, Vol. 6 No. 2, pp. 175-187.

Garcia, I., Giuliani, F., and Wiesenfeld, E. (1999), "Community and Sense of

Community: The Case of An Urban Barrio in Caracas”, Journal of Community Psychology, Vol. 27 No. 6, pp. 727-740.

Goddard T. (2005), "Corporate citizenship: Creating social capacity in developing Countries”, Development in Practice, Vol. 15, pp. 433-8

Global Reporting Initiative. (2008). Reporting on Community Impacts: A survey Conducted by the Global Reporting Initiatives, the University of Hong Kong and CSR Asia. Retrieved from http://www.globalreporting.org/. (accessed: 19 September 2008).

Godfrey, P. C. (2005), “The Relationship Between Corporate Philanthropy and Shareholder Wealth: A Risk Management Perspective”, Academy of Management Review, Vol. 30 No. 4, pp. 777-798.

Gossling, T., and Vocht, C. (2007), "Social Role Conceptions and CSR Policy Success. Journal of Business Ethics”, Vol. 74 No. 4, pp. 363-372.

Gyves, S., and O’Higgins, E. (2008), “Corporate social responsibility: an avenue for sustainable benefit for society and the firm?”, Society and Business Review, Vol. 3, No. 3, pp. 207-222.

Hamilton, S., Jo, H., and Statman, M. (1993), “Doing well while doing good? The investment performance of socially responsible mutual funds”, Financial Analyst Journal, Vol. 49, pp. 62-66.

Hansen, U. and Schrader, U. (1997), “A modern model of consumption for a sustainable Society”, Journal of Consumer Policy, Vol. 20 No.4, pp. 443-468.

Harvey, B. and Schaefer, A. (2001), “ Managing Relationships with Environmental Stakeholders: A Study of U. K. Water and Electricity Utilities”, Journal of Business Ethics, Vol. 30 No. 3, pp. 243-260.

Henderson, D. (2001). Misguided Virtue - False Notions of Corporate Social Responsibility. Wellington: New Zealand Business Roundtable. 
Heslin, P. A., and Ochoa, J. D. (2008), "Understanding and developing strategic corporate social responsibility”, Organizational Dynamics, Vol. 37 No. 2, pp. 125-144.

Hess, D., and Warren, D. E. (2008), “The Meaning and Meaningfulness of Corporate Social Initiatives”, Business and Society Review, Vol. 113 No.2, pp. 163-197.

Hess, D., Rogovsky, N., and Dunfee, T. W. (2002), "The Next Wave of Corporate Community Involvement: Corporate Social Initiatives”, California Management Review, Vol. 44 No.2, pp. 110-125

Holland, L., \& Gibbon, J. (2001). Processes in Social and Ethical Accountability-External Reporting Mechanisms in Andriof, J., McIntosh, M. Perspectives on Corporate Citizenship. Sheffield: Greenleaf Publishing.

Jenkins, H. (2006), “Small Business Champions for Corporate Social Responsibility”, Journal of Business Ethics, Vol. 67 No.3, pp. 241-256.

Keim, G. D. (1978), "Corporate Social Responsibility: An Assessment of the Enlightened Self-Interest Model”, The Academy of Management Review, Vol. 3 No. 1, pp. 32-39.

Korten, D. C. (1980), “Community Organization and Rural Development: A Learning Process Approach”, Public Administration Review, Vol. 40 No. 5, pp. 480-512.

Kotler, P., and Lee, N. (2005). Corporate Social Responsibility: Doing the Most Good for Your Company and Your Cause. New York: John Wiley and Sons.

Lafferty, B. A., and Goldsmith, R. E. (2005), "Cause--brand alliances: does the cause help the brand or does the brand help the cause?”, Journal of Business Research, Vol. 58 No. 4, pp. 423-429.

Lewis, S. (2003), "Reputation and corporate responsibility”, Journal of Communication Management, Vol. 7 No. 4, pp. 356-366.

Lichtenstein, D. R., Drumwright, M. E., and Braig, B. M. (2004), “The Effect of Corporate Social Responsibility Donations to Corporate-Supported Nonprofits”, Journal of Marketing, Vol. 68, pp.16-32.

Lincoln, Y. S., and Guba, E. G. (1985). Naturalistic Inquiry. Newbury Park, California: Sage Publications.

London Benchmarking Group. (2008), “ Improving the Management and Measurement of Community Involvement”, Retrieved from www.lbg-online.net.

(accessed: 20 February 2009).

London, T., and Hart, S. L. (2004), "Reinventing strategies for emerging markets: beyond the transnational model”, Journal of International Business Studies, Vol. 35 No. 5, pp. 350-370.

Lyons, M., and Zappalà, G. (2008). Not-for-profit organisations and business: Mapping the extent and scope of community-business partnerships in Australia. In J. Barraket (Ed.), Strategic Issues for the Not-for-Profit Sector. Sydney, Australia: UNSW Press. 
Mah, A. (2004). Uneasy Partnerships and Contradictions: Corporate Social and Environmental Responsibility. Paper presented at the Proceedings of the 3rd Annual Global Studies Association Conference Brandeis University.

Maio, E. (2003), “Managing brands in the new stakeholder environment”, Journal of Business Ethics, Vol. 44, nos 2/3, pp. 235-246.

Maignan, I. and Ralston, D. (2002), "Corporate Social Responsibility in Europe and the US: Insights from Business' Self Presentations”, Journal of International Business Studies, Vol. 33 No. 3, pp. 497-514.

Maignan, I. and Ferrell, O.C. (2004), “Corporate social responsibility and marketing: an Integrative Framework”, Journal of the Academy of Marketing Science, Vol. 32 No. 1, pp. 19-23.

Margolis, J. D. and Walsh, J. P. (2003), "Misery Loves Companies: Rethinking Social Initiatives by Business”, Administrative Science Quarterly, Vol. 48 No. 2, pp. 268-305.

Matten, D. and Crane, A. (2005), "Corporate Citizenship: toward an extended theoretical Conceptualization”, Academy of Management Review, Vol. 30 No. 1, pp. 166 -179 .

McDonald, C., and Warburton, J. R. (2003), "Stability and change in nonprofit organizations: The volunteer contribution”, International Journal of Voluntary and Nonprofit Organizations, Vol. 144, pp. 381-399.

McWilliams, A., and Siegel, D. S. (2001), “Corporate Social Responsibility: A Theory of Firm Perspective”, Academy of Management Review, Vol. 26 No. 1, pp.117-127.

McWilliams, A., Siegel, D. S., and Wright, P. M. (2006), “Corporate Social Responsibility: Strategic Implications”, Journal of Management Studies, Vol. 43 No. 1, pp. 1-18.

Miles, M. B., and Huberman, A. M. (1994). Qualitative data analysis: en expanded sourcebook. Thousand Oaks: Sage Publications.

Mitchell, R. K., Agle, B. R., and Wood, D. J. (1997), “Toward a Theory of Stakeholder Identification and Salience: Defining the Principle of Who and What Really Counts", Academy of Management Review, Vol. 22 No. 4, 853-886.

Mohr, L. A. and Webb, D. J. (2005), “The effects of corporate social responsibility and price of consumer responses”, Journal of Consumer Affairs, Vol. 39 No. 1,pp. 121-147.

Morimoto, R., Ash, J., and Hope, C. (2005), “Corporate Social Responsibility Audit: From Theory to Practice”, Journal of Business Ethics, Vol. 62 No. 4,pp. 315-325.

Murray, K.B. and Vogel, C.M. (1997), "Using a Hierarchy-of Effects Approach to Gauge the Effectiveness of Corporate Social Responsibility to Generate Goodwill Toward the Firm: Financial versus Non financial Impacts”, Journal of Business Research. Vol. 38, 141-159 
Oketch, M.O. (2005), “The Corporate Stake in Social Cohesion”, Peabody Journal of Education, Vol. 80 No. 4, pp. 30-52.

Orlitzky, M., Schmidt, F. L., and Rynes, S. L. (2003), “Corporate Social and Financial Performance: A Meta-analysis”, Organization Studies (01708406), Vol. 24 No. 3,pp. 403441.

Peloza, J. (2009), “The challenge of measuring financial impacts from investments in corporate social performance”, Journal of Management, Vol. 35 No. 6,pp. 1518-1541.

Peters, Veronika. (2001) Taking the First Steps: An Overview of Corporate Social Responsibility in Australia, Sydney: State Chamber of Commerce (NSW).

Pirsch, J., Gupta, S. and Grau, S. L (2006), “A Framework for Understanding Corporate Social Responsibility Progams as a Continuum: An Exploratory Study”, Journal of Business Ethics, Vol. 70,pp. 125-140.

Polonsky, M.J. and Scott, D. (2005), "An empirical examination of the stakeholder strategy mix”, European Journal of Marketing, Vol. 39 No. 9/10, pp. 1199-1215.

Pomering, A. and Johnson, L. (2009), “Advertising corporate social responsibility Initiatives To communicate corporate image: inhibiting scepticism to enhance persuasion”, Corporate Communications: An International Journal, Vol. 14 No.4, pp. 420 $-439$.

Porter, M. E., and Kramer, M. R. (2007), "Strategy and Society: The Link Between Competitive Advantage and Corporate Social Responsibility”, Harvard Business Review, Vol. 85, pp. 136-137

Post, F. (2003), “A response to the "social responsibility of corporate management: A classical critique”, Mid - American Journal of Business, Vol. 18 No. 1,pp. 25-35.

Prahalad, C. K. (2005). The Fortune at the Bottom of the Pyramid. Upper Saddle River, NJ: Wharton School Publishing.

Quaak, L., Aalbers, T., and Goedee, J. (2007), “Transparency of Corporate Social Responsibility in Dutch Breweries”, Journal of Business Ethics, Vol. 76 No. 3, pp. 293-308.

Raghubir, P., Roberts, J., Lemon, K., and Winer, R. (2010), "Why, When and How should the Effect of Marketing on the Community be measured? The AGE Framework for CSR Metrics”, Journal of Public Policy and Marketing, Vol. 29 No. 1,pp. 66-77.

Reed, A., and Reed, D. (2009), "Partnerships for Development: Four Models of Business Involvement”, Journal of Business Ethics, Vol. 90, pp. 3-37

Ricks, J. M. (2005), “An assessment of strategic corporate philanthropy on perceptions of brand equity variables”, Journal of Consumer Marketing, Vol. 22 No. (3),pp. 121-134. 
Ross, J.K., Patterson, L.T. and Stutts, M.A. (1992), “Consumer perceptions of organizations that use cause-related marketing”, Journal of the Academy of Marketing Science, Vol. 20 No. 1, pp. 93-97.

Rosthorn, J. (2000). Business Ethics Auditing - More Than a Stakeholder's Toy. Journal of Business Ethics, 27 (102), 9-19.

Russel, C. S. (1979). Collective Decision Making: Application from Public Choice Theory, Baltimore, The John Hopkins University Press.

Samuelson, P. A. (1954), “ The Pure Theory of Public Expenditure”, The Review of Economics and Statistics, Vol. 36 No. 4, pp. 387-389.

Saul, J. and Moroni, C. (2008). Measuring Corporate Social Impact: Why, What and How. Source:

http://www.missionmeasurement.com/system/files/Measuring+Corporate+Social+ImpactFraming+Paper.pdf. Retrieved: 6 July2011.

Scott, S. (2007), “Corporate Social Responsibility and the Fetter of Profitability”, Social Responsibility Journal, Vol. 3 No. 4, pp. 31-39.

Smith, N. C. (2003), “Corporate Social Responsibility: Whether or How? California Management Review”, Vol. 45 No. 4,pp. 52-76.

Smith, V. and Langford, P. (2009), "Evaluating the impact of corporate social Responsibility programs on consumers”, Journal of Management and Organization, Vol. 15 No.1, pp. 97-109.

Sriramesh, K., Ng, C. W., Soh, T. T., and Luo, W. (2009). "Corporate Social Responsibility (CSR) and Public Relations: Perceptions and Practices in Singapore" Paper presented at the annual meeting of the International Communication Association, Dresden International Congress Centre, Dresden, Germany. Retrieved from http://www.allacademic.com/meta/p91926_index.html. (accessed: 8 September 2009).

Starkey, R., \& Welford, R. (2001). Business \& Sustainable Development. London: Earthscan Publications.

Suggett, D., and Goodsir, B. (2002), “Triple Bottom Line Measurement and Reporting in Australia - Making it Tangible”, Sydney: The Allen Consulting Group.

Swanson, D. L. (1995), “Addressing a Theoretical Problem by Reorienting the Corporate Social Performance Model”, Academy of Management Review, Vol. 20 No. 1, pp. 43-64.

The Allen Consulting Group. (2007). Business for poverty relief: A business case for business action. Melbourne

The Economist. (2008). A survey of corporate social responsibility: just good business. Retrieved from: http://www.economist.com/node/10491077?story_id=10491077. (accessed: 21 June 2011). 
Van de Laan, S. (2009),'The role of theory in Explaining Motivation for Corporate Social Disclosures, Vol 3 No. 4, pp. 15-27.

Waddock, S. A., and Boyle, M. (2002), "The dynamics of change in corporate community Relations”, California Management Review, Vol. 37 No. 4,pp. 125-136.

Waddock, S. A., and Graves, S. B. (1997), “The Corporate Social Performance - Financial Performance Link”, Strategic Management Journal, Vol. 18 No. 4, pp 303-319.

Wheelams, M. (2007). The Role of CSR in Development: A Case Study Involving the Mining Industry in South America. St. Mary's University, Hallifax, NS Canada.

Weaver, G. R., Trevno, L. K., and Cochran, P. L. (1999), “Integrated and Decoupled Corporate Social Performance: Management Commitments, External Pressures, and Corporate Ethics Practices”, Academy of Management Journal, Vol. 42 No. 5,pp. 539-552.

Webb, D.J. and Mohr, L.A. (1998), “A typology of consumer responses to cause-related marketing: from skeptics to socially concerned”, Journal of Public Policy and Marketing, Vol. 17 No. 2,pp. 226-38.

Wood, J.D. (1991), “Corporate social performance revised”, Academy of Management Review, Vol. 16 No.4, pp. 691-718.

Wood, J. D., and Jones, R. E. (1995), "Stakeholders mismatching: A theoretical problem in empirical research on corporate social performance”, International Journal of Organizational Analysis, Vol 3, pp. 229-267.

Zadek, S. (2001). The civil corporation: The new economy of corporate citizenship. London: Earthscan.

Zappalà, G. (2004), “Corporate Citizenship and Human Resource Management: A New Tool or a Missed Opportunity”, Asia Pacific Journal of Human Resources, Vol. 42 No. 2,pp. 185201.

Zappalà, G. (2010). Beyond Corporate Responsibility: The 'Spiritual Turn' and the rise of Conscious Business. CSI Background Paper, 6( February).

Zappalà, G., and Cronin, C. (2002). The employee dimensions of Corporate Community Involvement in Australia: Trends and prospects, ANZTSR Conference, 27-29 November 2002. UNITEC, Auckland, New Zealand. 


\section{Appendix}

Table 1. Categories of externalities

\begin{tabular}{|c|c|c|}
\hline & Excludability & Nonexcludability \\
\hline Rivalry & $\begin{array}{l}\text { Private externality: } \\
\text { Stakeholders can be excluded. By } \\
\text { (involuntarily) internalizing the } \\
\text { externality, certain stakeholders } \\
\text { protect others. } \\
\text { For example: Coase's (1960) } \\
\text { example on the damage imposed on a } \\
\text { farmer's land by a cattle-raiser's } \\
\text { straying cattle. }\end{array}$ & $\begin{array}{l}\text { Common-pool externality: } \\
\text { Stakeholders cannot be excluded. By } \\
\text { (involuntarily) internalizing the } \\
\text { externality, certain stakeholders protect } \\
\text { others. } \\
\text { For example: Pigou's (1920) example of } \\
\text { sparks from trains systematically } \\
\text { causing fire outbreaks in the forests } \\
\text { bordering railroads. }\end{array}$ \\
\hline Nonrivalry & $\begin{array}{l}\text { Club externality: } \\
\text { Stakeholders can be excluded. All } \\
\text { stakeholders who are not excluded } \\
\text { take ownership of the externality } \\
\text { For example: consumption of fast } \\
\text { food which causes obesity }\end{array}$ & $\begin{array}{l}\text { Public externality: } \\
\text { Stakeholders cannot be excluded. All } \\
\text { stakeholders take ownership of the } \\
\text { externality. } \\
\text { For example: All stakeholders suffer } \\
\text { from CO2 building up by factories. No } \\
\text { escape from global warming }\end{array}$ \\
\hline
\end{tabular}

Source: Daudigeos \& Valiorgue (2011). Conditions for Value Creation in the Marketplace Through the Management of CSR issues: A Negative External Effects Framework. Business and Society, 50 (1), 28-49. 
Table 2. Overview of main findings concerning CSR/ CCI strategies in community involvement

\begin{tabular}{|c|c|}
\hline Main Findings & Source \\
\hline \multicolumn{2}{|l|}{ Type of strategies } \\
\hline \multirow{3}{*}{$\begin{array}{l}\text { 1. Donation } \\
\text { - Sponsorship } \\
\text { - Cause promotions and cause related marketing/ } \\
\text { philanthropic }\end{array}$} & Empirical research \\
\hline & Maignan \& Ralston, 2002 \\
\hline & Kotler \& Lee, 2005; Galbreath, 2006 \\
\hline \multirow{6}{*}{$\begin{array}{l}\text { 2. Employee volunteering } \\
\text { - Community volunteering }\end{array}$} & Empirical research \\
\hline & Maignan \& Ralston, 2002; McDonald \& Walburton, \\
\hline & 2003; \\
\hline & Kotler \& Lee, 2005 \\
\hline & Conceptual research \\
\hline & Hess et al., 2002 \\
\hline \multirow{2}{*}{$\begin{array}{l}\text { 3. Non-partnership } \\
\text { - Works directly with the recipient }\end{array}$} & Conceptual research \\
\hline & Hess et al., 2002 \\
\hline \multirow{12}{*}{$\begin{array}{l}\text { 4. Partnership } \\
\text { - Work with non-profit to address a social issue (s)/ } \\
\text { social alliances }\end{array}$} & Empirical research \\
\hline & London \& Hart, 2004; Kotler \& Lee, 2005 \\
\hline & Conceptual research \\
\hline & Korten, 1980; Brown \& Covey, 1987; Austin 2000 \\
\hline & Berger et al., 2004; Porter \& Kramer, 2007 \\
\hline & Empirical research \\
\hline & Weaver, Trevno \& Cochran, 1999; \\
\hline & London \& Hart, 2004; Bhattacharya et al, 2004; \\
\hline & Prahalad, 2005; Kotler \& Lee, 2005 \\
\hline & Conceptual research \\
\hline & Barney, 1991; Prahalad \& Hart, 2002; \\
\hline & Smith, 2003; Hess et al., 2002; Porter \& Kramer, 2007 \\
\hline
\end{tabular}


Table 3. Overview of main findings concerning CSR/ CCI consequences

\begin{tabular}{|c|c|}
\hline Main Findings & Source \\
\hline $\begin{array}{l}\text { Consequences } \\
\text { Positive impact on profit }\end{array}$ & $\begin{array}{l}\text { Empirical research } \\
\text { Margolish \& Walsh, 2001; Du, Sen, \& Bhattacharya, } \\
2008\end{array}$ \\
\hline $\begin{array}{l}\text { Positive impact on the present value of a firm's cash } \\
\text { flow }\end{array}$ & $\begin{array}{l}\text { Hamilton et al., 1993; Waddock \& Graves, 1997; } \\
\text { McWilliam \& Siegel, 2001, Godfrey, } 2005\end{array}$ \\
\hline $\begin{array}{l}\text { Corporate social irresponsibility increase public } \\
\text { cynicism }\end{array}$ & Aman, 2001; Cropanzano, et al., 2003 \\
\hline $\begin{array}{l}\text { Increases positive attitude toward the company and/or } \\
\text { the brand }\end{array}$ & $\begin{array}{l}\text { Dacin \& Brown, 1997; Lichtenstein et al., 2004; Kotler } \\
\text { and Lee, } 2005\end{array}$ \\
\hline $\begin{array}{l}\text { Increase in social participation and attitude to public \& } \\
\text { private sectors }\end{array}$ & Murray \& Vogel, 1997, Goddard, 2005 \\
\hline An Insurance policy in crisis situations & Dawar \& Pillutla, 2000 \\
\hline $\begin{array}{l}\text { Positive "spill over" effects to strategic alliances } \\
\text { (sponsorship, co-branding, not for profit organisation(s)) }\end{array}$ & $\begin{array}{l}\text { Ross et al., 1992; Cornwell \& Smith, 2001; } \\
\text { Lafferty \& Goldsmith, } 2005\end{array}$ \\
\hline $\begin{array}{l}\text { Social licence to operate \& create sustainable } \\
\text { competitiveness }\end{array}$ & Ellis, 1984; Wheelams, 2007 \\
\hline Positive effects to strategic alliances & $\begin{array}{l}\text { Conceptual research } \\
\text { Austin, 2000; Beckman, } 2007\end{array}$ \\
\hline
\end{tabular}


Table 4. Description of participants

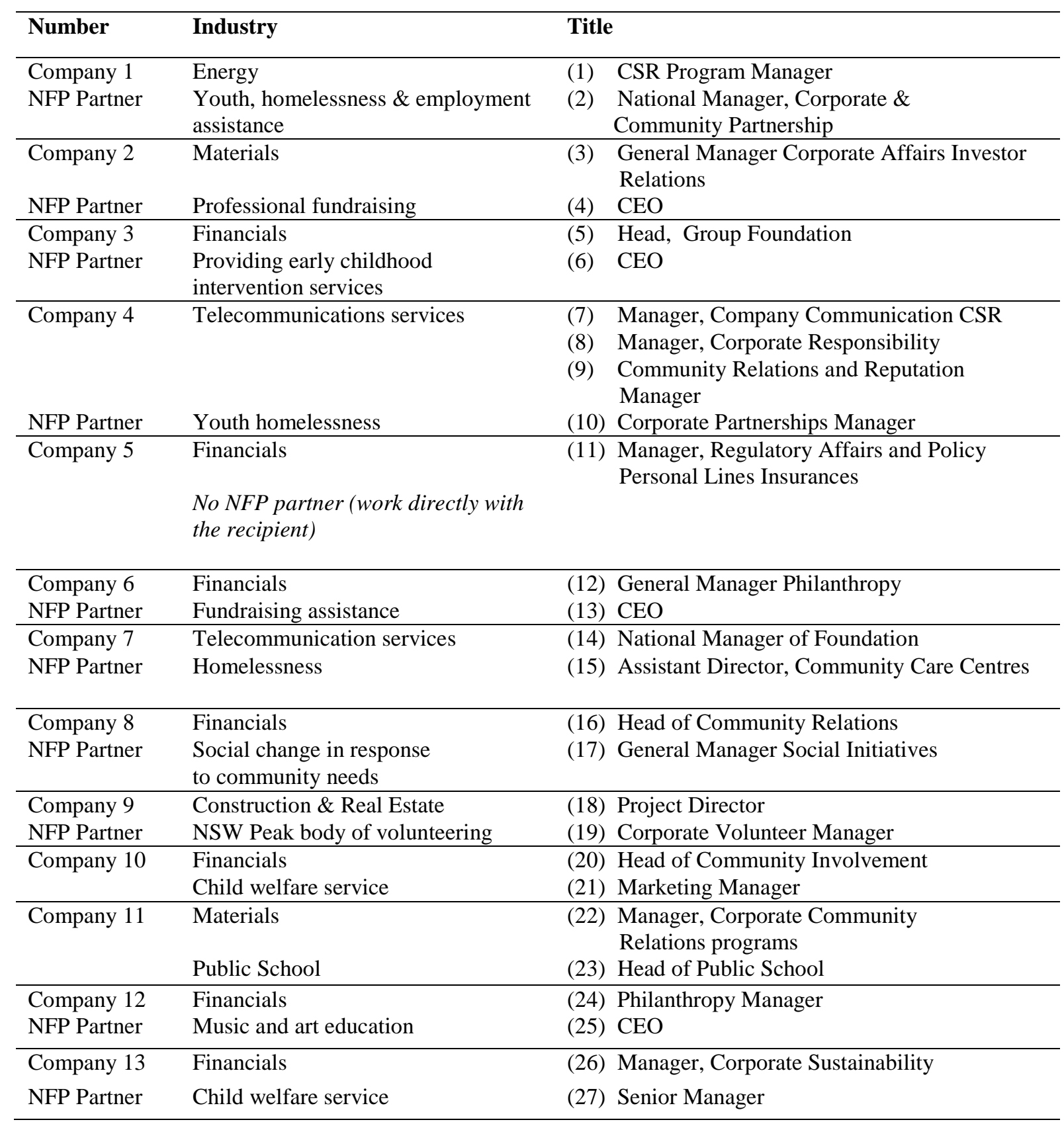


Table 5. List of interview questions

\section{Topic 1: Drivers of CCI in the company}

1. Do you have a 'general' CCI policy and strategy in the company? When was this formalized?

2. Is there a CCI division or department? Where is the CCI department's structural position in your company?

3. What were the reasons for commencing the CCI initiative in your company?

4. Who are your company's stakeholders? Do you engage with stakeholders to understand their expectation of the company?

5. What are the expectations of various groups of stakeholders? What are you currently doing that meets these expectations?

6. Are your employees involved in a program that you launch?

7. Do you have specific employee training to raise CCI awareness?

8. How do you inform your CCI program to your employees?

9. How do your employees respond to a program? Do they fully support the program?

\section{Topic 2: Social Impact Measurement}

10. What CCI community programs do you currently have?

11. What are the obstacles in formulating and maintaining CCI initiatives? How do you solve them?

12. Which area is your concentration in implementing CCI?

13. What result do you want to see?

14. How do you measure and evaluate the effectiveness of your programs? Why is this one regarded as successful?

15. What are some of the main challenges?

\section{Other}

15. Do you have any other suggestions for improving a CCI initiative?

16. Where do you see your 'CCI program' in the future?

17. What companies worldwide do you see as having the best CCI program? Why are they the best? [for benchmarking purposes). 